\title{
PENERAPAN MODEL PEMBELAJARAN MIND MAPPING DALAM MENINGKATKAN HASIL BELAJAR PADA MATA PELAJARAN ILMU PENGETAHUAN SOSIAL SISWA KELAS IV SDN 54 KOTA PAREPARE
}

\author{
Natriani Syam ${ }^{1}$, Ramlah ${ }^{2}$ \\ ${ }^{12}$ UPP PGSD Parepare Fakultas Ilmu Pendidikan UNM \\ natri.syam@gmail.com \\ ramlah@yahoo.com
}

\begin{abstract}
ABSTRAK
Tujuan penelitian ini yaitu untuk mengetahui proses penerapan model pembelajaran Mind Mapping pada mata pelajaran IPS tentang perkembangan teknologi di kelas IV SDN 54 Kota Parepare dan untuk meningkatkan hasil belajar IPS tentang perkembangan teknologi siswa kelas IV SDN 54 Kota parepare melalui penerapan model pembelajaran Mind Mapping. Pendekatan penelitian yang digunakan adalah pendekatan kualitatif dengan menggunakan jenis penelitian tindakan kelas (PTK). Subjek penelitian ini adalah peneliti dan siswa kelas IV SDN 54 Kota Parepare, sebanyak 26 orang yang terdiri dari 11 laki-laki dan 15 perempuan dan peneliti. Data diperoleh melalui teknik tes, observasi, dan dokumentasi. Data yang terkumpul dianalisis dengan menggunakan analisis data deskriptif kualitatif dengan cara mengelompokan data aspek guru dan aspek siswa. Tiap siklus dilaksanakan dalam 2 kali pertemuan. Pada siklus I hasil belajar masih dalam kategori cukup. Pada siklus II hasil belajar telah mencapai indikator keberhasilan dengan kategori baik. Kesimpulan hasil penelitian yaitu terjadi peningkatan hasil belajar IPS melalui penerapan model pembelajaran Mind Mapping pada siswa kelas IV SDN 54 Kota Parepare.
\end{abstract}

Kata kunci : Model Mind Mapping, Ilmu Pengetahuan Sosial, Hasil Belajar

\section{ABSTRACK}

The purpose of this study is to determine the application of learning models Mind Mapping in social studies about the development of technology in class IV SDN 54 Parepare and to improve learning outcomes IPS about technological developments fourth grade students of SDN 54 City Parepare through the application of learning models Mind Mapping. The approach used in this study is a qualitative approach using classroom action research (PTK). The subjects were researchers and fourth grade students of SDN 54 Parepare, as many as 26 people consisting of 11 men and 15 women and researchers. Data obtained through technical tests, observation, and documentation. Data were analyzed using qualitative descriptive data analysis by means of classifying the data aspects of teacher and student aspect. Each cycle performed in 2 sessions. In the first cycle of learning outcomes is still in the category enough. In the second cycle learning outcomes have achieved a good indicator of success with the category. Conclusion of the study, namely an increase in social studies results through the application of learning models Mind Mapping in the fourth grade students of SDN 54 Parepare.

Keywords : Model Mind Mapping, Social Science, Learning Outcomes

\section{PENDAHULUAN}

Pendidikan memegang peranan penting dalam mempersiapkan sumber daya manusia yang berkualitas dan mampu mengahadapi tantangan di masa depan dan berkompetisi dalam perkembangan ilmu pengetahuan dan teknologi. Pendidikan merupakan hal yang paling utama yang menjadi tolak ukur 
perkembangan suatu bangsa agar tidak tertinggal dari bangsa lain.

Berdasarkan tujuan mata pelajaran IPS di SD/MI siswa diharapkan mampu menyadari gejala sosial yang dihadapi dan memiliki kemampuan menyelesaikan secara logis sesuai dengan nilai-nilai sosial kemanusian. Konsep-konsep gejala sosial bersifat abstrak sehingga harus disosialisasikan dalam kegiatan pembelajaran. Keabstrakan konsep-konsep materi IPS menjadi hambatan belajar siswa dalam menguasai konsep (materi) tersebut.

Rendahnya hasil belajar siswa disebabkan oleh faktor siswa dan faktor guru itu sendiri. Berbagai Penyebabnya dapat diuraikan sebagai berikut: (1) Permasalahan yang disebabkansiswa antara lain: a. Siswa hanya belajar secara individual, b. Siswa kurang percaya diri dalam menyampaikan pendapatnya, c. Siswa hanya membuat catatan-catatan biasa yang bersifat monoton. Cara penerimaan informasi akan kurang efektif karena proses penguatan daya ingat hanya berupa catatan. Catatan yang dibuat oleh siswa hanya catatan yang bersifat monoton, siswa tidak dibiasakan berfikir atau menemukan ide secara kritis. Dan (2) Permasalahan yang disebabkan oleh guru antara lain : a. Guru kurang variatif dalam menerapkan metode pembelajaran, b. Guru hanya memberikan catatan biasa; c. Guru kurang membelajarkan siswa secara berkelompok.

Berdasarkan latar belakang tersebut, maka rumusan masalah pada penelitian ini dapat dirimuskan sebagai berikut (1) Bagaimanakah proses penerapan model pembelajaran Mind Mapping pada pembelajaran IPS tentang perkembangan teknologi di kelas IV SDN 54 Parepare? Dan (2) Apakah dengan menerapkan model pembelajaran Mind Mapping dapat meningkatan hasil belajar IPS tentang perkembangan teknologi siswa kelas IV SDN 54 Parepare?
Penelitian ini bertujuan (1) Untuk mengetahui proses penerapan model pembelajaran Mind Mapping pada mata pelajaran IPS tentang perkembangan teknologi di kelas IV SDN 54 Kota Parepare, dan (2) Untuk meningkatkan hasil belajar IPS tentang perkembangan teknologi siswa kelas IV SDN 54 Kota parepare melalui penerapan model pembelajaran Mind Mapping.

Mind Mapping merupakan salah satu konsep belajar yang paling revolusioner di dunia pendidikan. Dalam sejarah mencatat ada beberapa ahli yang berperan penting dalam perkembangan Mind Mapping. Beberapa ahli tersebut menurut Swadarma (2013: 5) adalah: Poephyry dari Tyre (234-305 M), seorang filusuf neoplatonist abad ketiga, memodifikasi konsep pengelompokan data Aristoteles menjadi model mapping sederhana dalam bentuk jari lingkaran. Selama berabad-abad digunakan oleh banyak orang untuk menganalisis dan memeberikan solusi atas berbagai macam permasalahan. Llull (1235-1315 M) seorang cendikiawan abad pertengahan Eropa mengembangkan konsep mapping berupa "Disc Lullian" dengan subjek berada di tengah lingkaran. Collins dan Quillian (1950-an), keduanya mengembangkan Mind Mapping diterapkan di dunia pendidikan atas konstibusinya keduanya dijuluki "Bapak Mind Mapping Modern”. Buzan memasuki tahun 1960-an, seseorang yang banyak menulis tentang human brain yang mempelajari bahwa sebenarnya manusia dilahirkan dengan jutaan lebih canggih dari komputer.

Shoimin (2014: 105) mengemukakan pengertian peta pikiran atau Mind Mapping bahwa: Pemetaan pikiran adalah teknik pemanfaatan seluruh otak dengan menggunakan citra visual dan prasarana grafis lainnya untuk membentuk kesan. Otak sering kali mengingat informasi dalam bentuk gambar, simbol, suara, bentuk-bentuk, dan perasaan. Peta ini dapat membangkitkan ide-ide orisinil dan memicu ingatan yang mudah. Ini jauh 
lebih mudah daripada metode pencatatan tradisional karena ia mengaktifkan kedua belahan otak. Cara ini menyenangkan, menenangkan, kreatif.

Dapat disimpulkan bahwa model pembelajaran Mind Map (peta pikiran) adalah model yang dirancang untuk membantu siswa dalam proses belajar, menyimpan informasi berupa materi pelajaran yang diterima oleh siswa pada saat pembelajaran, dan membantu siswa menyusun inti-inti yang penting dari materi pelajaran ke dalam bentuk peta, grafik maupun penggunaan simbol sehingga siswa lebih mudah mengingat pelajaran tersebut. Melalui model pembelajaran Mind Mapping, siswa tidak lagi dituntut untuk selalu mecatat tulisan yang ada di papan tulis atau yang didiktekan oleh guru secara keseluruhan. Siswa akan mengetahui inti masalah, kemudian membuat peta pikirannya masing-masing sesuai dengan kreativitas mereka.

Menurut Buzan (2008: 171) bahwa Mind Map (peta pikiran) ini akan membantu anak:

a) Mudah mengingat sesuatu;

b) Mengingat fakta, Angka, dan Rumus dengan mudah;

c) Meningkatkan motivasi dan konsentrasi;

d) Mengingat dan menghafal menjadi lebih cepat.

Keunggulan lain dari model pembelajaran Mind Mapping dijelaskan oleh Swadarma (2013: 9) yakni:

a) eningkatkan kinerja manajemen pengetahuan;

b)

emaksimalkan sistem kerja otak;

c)

aling berhubungan satu sama lain sehingga makin banyak ide dan informasi yang dapat dijelaskan; d)

emacu kreativitas, sederhana dan mudah dikerjakan;

e)

ewaktu-waktu dapat me-recall data yang ada dengan mudah.

Kegiatan pembelajaran dengan menggunakan model pembelajaran Mind Mapping ada beberapa langkah yang dijelaskan oleh Shoimin (2014), langkah-langkahnya adalah sebagai berikut: 1) Guru menyampaikan tujuan pembelajaran yang ingin dicapai, 2) Guru menyajikan materi, 3) Siswa dibagi kedalam beberapa kelompok yang anggotanya 2 orang, 4) Siswa merancang peta pikiran, 5) Siswa mempresentasekan hasil diskusi secara berkelompok, 6) Kesimpulan.

Contoh Mind Mapping dengan tema utama dan cabangnya dan kemudian sub-sub cabang. Berikut contoh Mind Mapping menurut Buzan (2008: 21)

Ilmu Pengetahuan Sosial merupakan salah satu mata pelajaran yang diberikan mulai dari SD/MI/SDLB sampai SMP/MTs/SMPLB. IPS mengkaji seperangkat peristiwa, fakta, konsep dan generalisasi yang berkaitan dengan isu sosial. Menurut Kurikulum Standar Isi, dalam KTSP (2006) pada jenjang SD/MI mata pelajaran IPS memuat materi Geografi, Sejarah, Sosiologi dan Ekonomi.

KTSP (2006) mata pelajaran IPS SD/MI disebutkan bahwa mata pelajaran IPS di $\mathrm{SD} / \mathrm{MI}$ bertujuan agar peserta didik memiliki kemampuan yaitu 1) Mengenal konsep-konsep yang berkaitan dengan kehidupan masyarakat dan lingkungannya, 2)Memiliki kemampuan dasar untuk berfikir logis dan kritis, rasa ingin tahu, inkuiri, memecahkan masalah, dan keterampilan dalam kehidupan sosial, 3) Memiliki komitmen dan kesadaran terhadap nilai-nilai sosial dan kemanusiaan, 4) Memiliki kemampuan berkomunikasi, bekerjasama, dan berkompetisi dalam masyarakat yang majemuk 
di tingkat lokal, nasional, dan global.

Gagne (Swadarma, 2013:

menjelaskan bahwa hasil belajar merupakan "kemampuan-kemampuan yang dimiliki peserta didik sebagai akibat perbuatan belajar dan dapat diamati melalui penampilan peserta didik". Hasil belajar merupakan kemampuan yang dimiliki oleh peserta didik dari proses belajar yang dapat dilihat dari sikap, berbagai pengetahuan, dan berbagai keterampilan yang dimilikinya.

\section{METODE PENELITIAN}

Jenis penelitian yang digunakan adalah Penelitian Tindakan Kelas. Penelitian dilaksanakan di kelas IV SDN 54 Kota Parepare, pada Semester genap tahun ajaran 2014/2015 yang dimulai pada bulan Maret sampai selesai. Waktu tersebut dimulai dari tahap perencanaan sampai tahap laporan. Bidang kajian yang telah diteliti terkhusus kepada mata pelajaran IPS. Subjek penelitian adalah guru dan siswa kelas IV SDN 54 Parepare, dengan jumlah siswa kelas IV adalah 26 orang yang terdiri dari 11 siswa laki-laki 15 siswa perempuan.

Penelitian ini peneliti menggunakan metode PTK Kemmis \& Mc. Taggart yang dalam alur penelitiannya yakni meliputi langkah-langkah: 1. Perencanaan (Plan). 2. Pelaksanaan Tindakan (Act), 3. Pengamatan (Observe), dan 4. Refleksi (Reflection). Hasil refleksi ini kemudian dipergunakan untuk memperbaiki perencanaan (Revise Plan) siklus berikutnya.

Untuk pengumpulan data dalam penelitian ini dilakukan dengan tes, observasi, dan dokumentasi. Tiga teknik tersebut diuraikan sebagai berikut:

\section{Tes}

Tes hasil belajar dilakukan peneliti untuk mengumpulkan data mengenai peningkatan hasil belajar siswa. Pelaksanaan tes dilakukan pada setiap akhir siklus.

2. Observasi
Observasi dilakukan peneliti dengan cara mengumpulkan data mengenai aktivitas mengajar guru dan aktivitas belajar siswa kelas IV SDN 54 Kota Parepare selama proses pembelajaran berlangsung dengan menggunakan lembar observasi siswa dan guru.

3. Dokumentasi

Berupa sekumpulan data yang diperoleh dari kepala sekolah dan guru kelas mengenai data awal siswa, serta data yang nantinya diperoleh dari hasil penelitian.

Analisis data yang digunakan dalam penelitian ini adalah analisis data deskriftif kualitatif yang dikembangkan oleh Miles dan Huberman, terdiri atas tiga tahap kegiatan yaitu:

1) mereduksi data, adalah proses kegiatan menyeleksi, memfokuskan dan menyederhanakan semua data yang telah diperoleh mulai dari awal pengumpulan data sampai penyusunan laporan penelitian.

2) Menyajikan data adalah kegiatan mengorganisasikan hasil reduksi dengan cara menyusun secara naratif sekumpulan informasi yang telah diperoleh dari hasil reduksi sehingga dapat memberikan kemungkinan penarikan kesimpulan dan pengambilan tindakan.

3) Menarik kesimpulan atau verifikasi data adalah memberikan kesimpulan terhadap hasil penafsiran dan evaluasi yang mencakup pencarian makna data serta memberikan penjelasan selanjutnya.

Berdasarkan kriteria standar keberhasilan tersebut maka dalam penelitian ini ada dua macam indikator keberhasilan yang akan dicapai, yaitu indikator tentang keterlaksanaan pembelajaran dan indikator peningkatan hasil belajar siswa. Pembelajaran dikatakan terlaksana dengan baik apabila minimal $76 \%$ kegiatan pembelajaran yang telah direncanakan terlaksana dengan baik atau berkualifikasi Baik (B). Adapun siswa dikatakan berhasil apabila minimal $76 \%$ siswa 
telah memperoleh nilai $\geq 70$.

\section{HASIL DAN PEMBAHASAN}

Penelitian ini terdiri dari dua siklus, masing-masing tahapan tiap siklus diuraikan sebagai berikut :

\section{Siklus I}

1. Perencanaan

Kegiatan pada tahap perencanaan ini antara lain adalah :

a) Menganalisis materi pelajaran dimana pada siklus 1 pertemuan pertama akan dibahas yaitu perkembangan teknologi secara umum atau lebih jelasnya "Jenis-Jenis Teknologi" dan pada pertemuan kedua materi pelajaran yang akan dibahas yaitu "Perkembangan Teknologi Produksi masa lalu dan masa kini”.

b) Membuat Rencana Pelaksanaan Pembelajaran (RPP) untuk setiap pertemuan (2 kali pertemuan) dalam siklus I.

c) Membuat lembar observasi guru dan siswa yang berorientasi pada model pembelajaran Mind Mapping untuk mengamati proses pembelajaran selama pelaksanaan setiap pertemuan.

d) Mempersiapkan media pembelajaran berupa gambar telepon rumah, handphone, laptop pada pertemuan pertama dan gambar-gambar alat-alat teknologi produksi pada pertemuan kedua.

e) Membuat lembar tes formatif untuk dievaluasikan pada akhir pembelajaran beserta kunci jawaban dan pedoman penskoran.

f) Mempersiapkan alat dokumentasi berupa kamera untuk mendokumentasikan proses pembelajaran yang akan dilaksanakan.

2. pelaksanaan

Tahap pelaksanaan terdiri dari dua pertemuan, pertemuan pertama dilaksanakan dengan sebagai berikut :

Guru masuk ke kelas dan mengawali pelajaran dengan mengucapkan salam dan berdoa serta mengecek kehadiran siswa.
Kemudian peneliti mengkondisikan siswa untuk siap mengikuti pelajaran IPS. Pada pertemuan pertama guru mengadakan apersepsi dengan memberikan pertanyaan kepada siswa yang berkaitan dengan materi yang akan diajarkan, "selain mengirim surat, bagaimana cara kalian memberi informasi kepada guru kalian ketika kalian sakit?". Kemudian siswa menjawab dengan berbagai macam pendapat mereka. Pada tahap kegiatan inti pembelajaran, guru memulai pembelajaran dengan melaksanakan langkah-langkah model pembelajaran Mind Mapping yaitu:

Pada tahap menyampaikan tujuan pembelajaran, kegiatan yang dilakukan guru adalah menuliskan dan menyampaikan serta menjelaskan tujuan pembelajaran, kemudian siswa dipersilahkan menuliskan tujuan pembelajaran tersebut. Pada tahap ini guru juga menjelaskan kepada siswa manfaat mempelajari tentang "Jenis-Jenis Teknologi" Pada tahap ini, guru juga menyampaikan kompetensi yang akan dilakukan oleh siswa nantinya.

Pada tahap menyajikan materi pelajaran, kegiatan yang dilakukan pada pembelajaran ini yaitu guru menjelaskan pengertian teknologi dan "Jenis-Jenis Teknologi" dengan memanfaatkan media yang telah disediakan yaitu gambar, telepon rumah, dan handphone. Sementara siswa menyimak penjelasan materi pelajaran tersebut diselingi juga dengan tanya jawab antara guru dan siswa sebagi bentuk respon siswa terhadap penyampaian materi pelajaran tersebut.

Pada tahap membagi siswa kedalam bentuk kelompok, Guru megelola kelas dalam bentuk kelompok kecil dimana pada saat itu siswa dibagi menjadi 13 kelompok yang masing-masing kelompok beranggotakan 2 orang siswa setiap kelompoknya. Guru membagi kelompok sesuai kelengkapan alat yang telah dibawa oleh siswa karena dalam diskusi nanti siswa membutuhkan spidol atau pensil warna untuk merancang peta pikirannya. 
Sementara, hanya beberapa siswa yang membawa spidol atau pensil warna. Jadi, guru mengatur sedemikian rupa agar semua kelompok memiliki spidol atau pensil warna. Kemudian membagikan Lembar Kerja Kelompok (LKK), menjelaskan petunjuk kerja, dan mempersilahkan siswa berdiskusi/bertanya jawab dengan teman kelompoknya seputar materi tentang "Jenis-Jenis Teknologi" yang baru saja dijelaskan oleh guru.

Pada tahap mengamati dan membimbing siswa merancang peta pikiran, kegiatan yang dilakukan dalam tahap ini adalah guru membimbing setiap kelompok dalam merancang peta pikiran sesuai petunjuk kerja pada LKK yang telah dibagikan. Pada tahap ini, guru mempersilahkan kepada siswa langsung bertanya ketika mendapat kesulitan dalam merancang peta pikiran tentang "Jenis-Jenis Teknologi". Sementara kegiatan yang dilakukan siswa merancang peta pikiran sesuai kreativitasnya masing-masing.

Pada tahap mengamati dan membimbing siswa saat presentase, kegiatan yang dilakukan pada tahap ini adalah guru mengacak kelompok siswa untuk melakukan presentase di depan guru dan dan teman-teman lainnya. Siswa secara bergantian menyampaikan atau mempresentasekan hasil kerja kelompok mereka diselingi dengan pemberian penguatan oleh guru untuk percaya diri membacakan hasil kerja kelompok di depan guru dan teman-teman lainnya agar siswa terbiasa berbicara di depan umum.

Pada tahap menyimpulkan pembelajaran, guru mengarahkan siswa untuk merumuskan kesimpulan berdasarkan pelajaran. Guru membimbing siswa untuk menyampaikan apa yang telah siswa ketahui tentang materi pelajaran yang telah dipelajari mengenai "Jenis-Jenis Teknologi". Siswa secara bergantian mengeluarkan pendapat mereka berdasarkan apa yang telah siswa ketahui.

Pada kegiatan akhir pertemuan pertama siklus I, guru memberikan pesan moral untuk senantiasa mengulangi pembelajaran di rumah maupun di sekolah serta mensyukuri adanya perkembangan teknologi saat ini dengan memanfaatkan teknologi sebaik-baiknya.

Pertemuan dua, dilaksanakan sebagai berikut :

Pada tahap kegiatan inti pembelajaran, guru memulai pembelajaran dengan melaksanakan langkah-langkah model pembelajaran Mind Mapping yaitu:

Pada tahap menyampaikan tujuan pembelajaran, kegiatan yang dilakukan guru adalah menuliskan dan menyampaikan serta menjelaskan tujuan pembelajaran, kemudian siswa dipersilahkan menuliskan tujuan pembelajaran tersebut. Pada tahap ini guru juga menjelaskan kepada siswa manfaat mempelajari tentang "Perkembangan Teknologi Produksi”. Pada tahap ini, guru juga menyampaikan kompetensi yang akan dilakukan oleh siswa nantinya.

Pada tahap menyajikan materi pelajaran, kegiatan yang dilakukan pada pembelajaran ini yaitu, guru menjelaskan pengertian teknologi dan "Perkembangan Teknologi Produksi" dengan memanfaatkan media yang telah disediakan yaitu gambar. Sementara siswa menyimak penjelasan materi pelajaran tersebut diselingi juga dengan tanya jawab antara guru dan siswa sebagi bentuk respon siswa terhadap penyampaian materi pelajaran tersebut.

Pada tahap membagi siswa kedalam bentuk kelompok, peneliti megelola kelas dalam bentuk kelompok kecil dimana pada saat itu siswa dibagi menjadi 13 kelompok yang masing-masing kelompok beranggotakan 2 orang siswa setiap kelompoknya. Guru membagi kelompok sesuai kelengkapan alat yang telah dibawa oleh siswa karena dalam diskusi nanti siswa membutuhkan spidol atau pensil warna untuk merancang peta pikirannya. Sementara, hanya beberapa siswa yang membawa spidol atau pensil warna. Jadi, guru mengatur sedemikian rupa agar semua kelompok memiliki spidol atau pensil warna. Kemudian membagikan Lembar Kerja 
Kelompok (LKK), menjelaskan petunjuk kerja, dan mempersilahkan siswa berdiskusi/bertanya jawab dengan teman kelompoknya seputar materi tentang "Perkembangan Teknologi Produksi" yang baru saja dijelaskan oleh guru.

$$
\text { Pada tahap mengamati dan }
$$
membimbing siswa dalam merancang peta pikiran, kegiatan yang dilakukan dalam tahap ini adalah guru membimbing setiap kelompok dalam merancang peta pikiran sesuai petunjuk kerja pada LKK yang telah dibagikan. Pada tahap ini, guru mempersilahkan kepada siswa langsung bertanya ketika mendapat kesulitan dalam merancang peta pikiran tentang Perkembangan Teknologi Produksi”. Sementara kegiatan yang dilakukan siswa merancang peta pikiran sesuai kreativitas mereka masing-masing.

Pada tahap mengamati dan membimbing siswa saat presentase, kegiatan yang dilakukan pada tahap ini adalah guru mengacak kelompok siswa untuk melakukan presentase di depan guru dan dan teman-teman lainnya. Siswa secara bergantian menyampaikan atau mempresentasekan hasil kerja kelompok mereka diselingi dengan pemberian penguatan oleh guru untuk percaya diri membacakan hasil kerja kelompok di depan guru dan teman-teman lainnya agar siswa terbiasa berbicara di depan umum.

Pada tahap menyimpulkan pembelajaran, guru mengarahkan siswa untuk merumuskan kesimpulan berdasarkan pelajaran. Guru membimbing siswa untuk menyampaikan apa yang telah siswa ketahui tentang materi pelajaran yang telah dipelajari mengenai "Perkembangan Teknologi Produksi". Siswa secara bergantian mengeluarkan pendapat mereka berdasarkan apa yang telah siswa ketahui.

Kemudian guru memberikan tes evaluasi akhir siklus yang bertujuan untuk mengecek apakah siswa sudah benar-banar memahami materi pembelajaran dan mengukur pencapaian keberhasilan belajar pada siklus I.
Hasil evaluasi akhir siklus I, menunjukkan nilai yang sesuai dengan Kriteria Ketuntasan Minimal (KKM) $\geq 70$ hanya mencapai $73 \%$ atau berada pada kategori cukup (C) siswa mencapai kategori tuntas dan selebihnya $27 \%$ belum mencapai nilai KKM. Pencapaian tersebut belum mencapai target keberhasilan yang telah ditetapkan yaitu minimal 76\% siswa memperoleh nilai $\geq 70$, maka pembelajaran harus dilanjutkan ke siklus II. Hal ini dikarenakan dalam proses pembelajaran aktivitas guru dan siswa yang masih belum terbiasa dengan menerapkan model pembelajaran Mind Mapping dalam proses pembelajaran. Sehingga, pada tahap evaluasi akhir siklus I hasil yang didapatkan belum mencapai keberhasilan belajar sesuai yang ditargetkan.

3. Observasi

Adapun temuan hasil observasi terhadap guru yang dilakukan pada siklus I pertemuan I yaitu:

a) Pada tahap menyampaikan tujuan pembelajaran, terlihat aktivitas guru melaksanakan 3 dari 3 deskriptor baik pada pertemuan pertama dan kedua siklus I sehingga pada tahap ini mencapai kategori baik (B).

b) Pada tahap menyaikan materi pelajaran, pertemuan pertama siklus I masih berada pada kategori kurang (K) karena hanya 1 dari 3 deskriptor terlaksana yaitu guru hanya guru menjelaskan materi pokok berdasarkan indikator pembelajaran. Namun, tidak secara sistematis dan terdapat bahasa yang digunakan guru yang masih sulit dipahami oleh siswa. Kemudian meningkat pada pertemuan kedua dimana guru telah menjelaskan materi pokok berdasarkan indikator/tujuan pembelajaran, menjelaskan materi pokok secara singkat dan sistematis namun masih terdapat bahasa yang sulit dipahami siswa. Sehingga sedikit meningkat menjadi kategori cukup (C). 
c) Pada tahap membagi siswa kedalam 13 kelompok yang beranggotakan 2 siswa perkelompok, 2 dari 3 deskriptor terlaksana baik pada pertemuan pertama dan kedua yaitu membagikan siswa bacaan sesuai materi yang dijelaskan dan membagikan LKK. Namun, penjelasan petunjuk kerjanya kurang dipahami siswa sehingg siswa masih banyak belum mengerti dan saat mengerjakannya masih banyak kesulitan. Sehingga pada tahap ini masih berada pada kategori cukup (C).

d) Pada tahap membimbing dan mengamati siswa saat merancang peta pikiran, 2 dari 3 deskriptor terlaksana baik pada pertemuan pertama dan kedua yaitu mendatangi semua kelompok, memberikan stimulus agar kelompok yang masih belum memahami langsung bertanya. Namun, belum sepenuhnya membimbing siswa dalam merancang peta pikiran. Sehingga pada tahap ini masih berada pada kategori cukup (C).

e) Pada tahap membimbing dan mengamati siswa saat mempresentasekan hasil kerja kelompok, 2 dari 3 deskriptor terlaksana baik pada pertemuan pertama dan kedua yaitu mengacak kelompok yang mempresentasekan hasil kerja kelompoknya di depan kelas, meminta siswa membacakan hasil diskusinya dengan percaya diri, namun guru tidak mengarahkan siswa membacakannya sesuai hasil kerja masing-masing kelompok. Sehingga pada tahap ini masih berada pada kategori cukup (C).

f) Pada tahap menyimpulkan, pada pertemuan pertama dan kedua hanya 1 dari 3 dekriptor telaksana yaitu mengarahkan siswa untuk merumuskan kesimpulan dari pembelajaran. Karena terlalu lama saat presentase kelompok, sehingga pada tahap kesimpulan, guru hanya sempat mengarahkan siswa merumuskan kesimpulan pembelajaran. Guru tidak sempat meminta menuliskan dan membacakannya karena waktu istirahat sudah masuk.Sehingga pada tahap ini berada pada kategori kurang (K).

Berdasarkan hasil observasi pelaksanaan tindakan siklus I, dapat dijelaskan bahwa pembelajaran belum mencapai hasil maksimal walaupun sudah mengalami peningkatan dari pertemuan I ke pertemuan II. Jadi secara keseluruhan hasil aktivitas guru yaitu $61,11 \%$ dan berada pada kategori cukup (C) dan pertemuan kedua dengan presntase $72,22 \%$ dan juga masih berada kategori cukup (C). Hal ini terjadi karena guru (peneliti) masih gugup dalam melaksanakan pembelajaran pada pertemuan pertama. Sedangkan temuan hasil observasi terhadap siswa yang dilakukan pada siklus I adalah sebagai berikut:

a) Pada tahap menyimak ulasan tujuan pembelajaran, pada pertemuan pertama 5 kelompok berada pada kategori baik (B), 2 kelompok berada pada kategori cukup (C), dan 6 kelompok barada pada kategori kurang (K). Kemudian sedikit meningkat pada pertemuan kedua dimana 6 kelompok berada pada kategori baik (B), 7 kelompok berada pada kategori cukup (C), dan tidak ada lagi yang berada pada kategori kurang (K).

b) Pada tahap menyimak penyajian materi pelajaran, tidak ada kelompok yang berada pada kategori baik (B), 7 kelompok berada pada kategori cukup (C), dan 6 kelompok berada pada kategori kurang (K). Kemudian sedikit meningkat pada pertemuan kedua masih tidak ada kelompok yang berada pada kategori baik (B), 12 kelompok berada pada kategori cukup (C), dan tersisa 1 kelompok yang masih berada pada kategori kurang $(\mathrm{K})$.

c) Pada tahap berdiskusi dengan teman kelompok, pada pertemuan pertama 3 kelompok berada pada kategori baik (B), 5 kelompok berada pada kategori cukup (C), dan juga ada 5 kelompok berada pada kategori kurang (K). Kemudian sedikit 
meningkat pada pertemuan kedua dimana 8 kelompok berada pada kategori baik (B), 5 kelompok berada pada kategori cukup (C), dan tidak ada lagi yang berada pada kategori kurang (K).

d) Pada tahap merancang peta pikiran, pada pertemuan pertama 4 kelompok berada pada kategori baik (B), 4 kelompok berada pada kategori cukup (C), dan 5 kelompok berada pada kategori kurang (K). Kemudian sedikit meningkat pada pertemuan kedua dimana 4 kelompok berada pada kategori baik (B), dan 9 kelompok berada pada kategori cukup (C), dan tidak ada lagi yang berada pada kategori kurang $(\mathrm{K})$.

e) Pada tahap mempresentasekan, pada pertemuan pertama 3 kelompok berada pada kategori baik (B), 7 kelompok berada pada kategori cukup (C), dan 3 kelompok berada pada kategori kurang (K). Kemudian sedikit meningkat pada pertemuan kedua dimana 5 kelompok berada pada kategori (B), 7 kelompok berada pada kategori kurang $(\mathrm{K})$, dan tersisa 1 kelompok berada pada kategori kurang (K).

f) Pada tahap menyimpulkan, pada pertemuan pertama tidak ada kelompok yang berada pada kategori baik dan cukup dalam arti semua kelompok berada pada kategori kurang (K). Hal ini dikarenakan siswa belum percaya diri dan terbiasa menyampaikan pendapatnya. Namun, terlihat sedikit meningkat pada pertemuan kedua meskipun tidak ada yang berada pada kategori baik (B) dimana 3 kelompok berada pada kategori cukup (C), dan 10 kelompok berada pada kategori kurang $(\mathrm{K})$.

Berdasarkan observasi tersebut presentase keseluruhan aktivitas siswa pada proses pembelajaran pada pertemuan pertama yaitu $56,83 \%$ berada pada kategori kurang $(\mathrm{K})$ dan meningkat pada pertemuan kedua dengan presentase $71,78 \%$ berada pada kategori cukup (C).

\section{Refleksi}

Secara umum pelaksanaan tindakan belum sesuai dengan rencana pelaksanaan pembelajaran yang telah dibuat. Namun semua tahap-tahap pelaksanaan pembelajaran dengan menerapkan model pembelajaran Mind Mapping telah dilaksanakan, meskipun masih ada beberapa deskriptor yang belum terlaksana. Adapun beberapa yang belum terlaksana pada siklus I adalah sebagai berikut:

a) Peneliti belum menyajikan atau menjelaskan materi pelajaran secara sistematis dan dengan bahasa yang mudah dipahami oleh siswa.

b) Peneliti belum membagi kelompok dengan teliti sehingga masih terdapat kelompok merupakan gabungan antara siswa yang memiliki kemampuan lebih dan terdapat kelompok merupakan gabungan siswa yang kemampuannya masih kurang.

c) Pada tahap menyajikan/menjelaskan materi terjadi peningkatan aktivitas yaitu dari kategori kurang menjadi cukup.

d) Peneliti belum menggunakan waktu secara efisien, sehingga pembelajaran yang direncanakan tidak sesuai dengan yang dilaksanakan terutama pada tahap menyimpulkan. Sedangkan hasil observasi terhadap aktivitas siswa menunjukan hal-hal sebagai berikut:

a) Siswa belum begitu memahami cara membuat catatan kecil/merancang peta pikiran.

b) Siswa masih kurang berani mengeluarkan pendapatnya terutama pada langkah menyimpulkan.

Hasil observasi dan evaluasi tersebut baik pada pertemuan pertama maupun kedua siklus I masih terdapat banyak kekurangan yang harus diperbaiki atau disempurnakan pada siklus II, maka peneliti dan pengamat mendiskusikan hal-hal yang perlu disempurnakan pada siklus II yaitu:

a) Peneliti harus menguasai materi pelajaran dan guru harus lebih mensistematiskan 
penjelasan dan menggunakan bahasa yang mudah dipahami oleh siswa.

b) Peneliti dalam mengelolah kelas harus lebih baik lagi terutama dalam pembagian kelompok, guru harus lebih teliti dalam mengatur kelompok siswa karena hal tersebut dapat mempengaruhi kerjasama siswa dalam proses diskusi dan membuat catatan-catatan kecil/merancang peta pikiran.

c) Peneliti harus lebih menuntun siswa dalam membuat catatan-catatan kecil/merancang peta pikiran.

d) Peneliti harus mampu memanage atau mengatur waktu dalam menyelesaikan langkah-langkah pembelajaran dengan menerapkan model pembelajaran Mind Mapping agar waktu dapat dimanfaatkan sebaik mungkin.

e) Peneliti harus lebih membimbing siswa dalam menyimpulkan pembelajaran.

\section{Siklus 2}

\section{Perencanaan}

Selanjutnya pada perencanaan tindakan siklus II, peneliti melakukan hal-hal sebagai berikut:

a) Menyusun Rencana Pelaksanaan Pembelajaran (RPP) untuk 2 kali pertemuan siklus II dengan tetap mengacu pada kurikulum dan tetap berorientasi pada langkah-langkah pembelajaran dengan menerapkan model pembelajaran Mind Mapping dengan melanjutkan materi pelajaran "Perkembangan Teknologi Komunikasi" pada pertemuan pertama siklus II dan "Perkembangan Teknologi Transportasi" pada pertemuan kedua.

b) Menyusun rambu-rambu untuk mengetahui gambaran pelaksanaan proses pembelajaran, meliputi lembar observasi guru dan lembar observasi siswa.

c) Menyiapkan media pembelajaran berupa gambar-gambar perkembangan teknologi komunikasi dan transportasi. d) Menyiapkan tes formatif untuk pelaksanaan evaluasi siklus II yang diadakan di akhir pertemuan siklus.

e) Mempersiapkan alat dokumentasi berupa kamera untuk mendokumentasikan proses pembelajaran yang akan dilaksanakan.

2. Pelaksanaan

Tahap pelaksanaan terdiri dari dua pertemuan, pertemuan pertama antara lain sebagai berikut :

Pada tahap kegiatan inti pembelajaran, guru memulai pembelajaran dengan melaksanakan langkah-langkah model pembelajaran Mind Mapping yaitu:

Pada tahap menyampaikan tujuan pembelajaran, kegiatan yang dilakukan guru adalah menuliskan dan menyampaikan serta menjelaskan tujuan pembelajaran, kemudian siswa dipersilahkan menuliskan tujuan pembelajaran tersebut. Pada tahap ini guru juga menjelaskan kepada siswa manfaat mempelajari tentang "Perkembangan Teknologi Komunikasi" Pada tahap ini, guru juga menyampaikan kompetensi yang akan dilakukan oleh siswa nantinya.

Pada tahap menyajikan materi pelajaran, kegiatan yang dilakukan pada pembelajaran ini yaitu, guru menjelaskan pengertian teknologi dan "“Perkembangan Teknologi Komunikasi” dengan memanfaatkan media gambar dan handphone yang telah disediakan. Sementara siswa menyimak penjelasan materi pelajaran tersebut diselingi juga dengan tanya jawab antara guru dan siswa sebagi bentuk respon siswa terhadap penyampaian materi pelajaran tersebut.

Pada tahap membagi siswa kedalam bentuk kelompok, Guru megelola kelas dalam bentuk kelompok kecil dimana pada saat itu siswa dibagi menjadi 13 kelompok yang masing-masing kelompok beranggotakan 2 orang siswa setiap kelompoknya. Guru membagi kelompok sesuai kelengkapan alat yang telah dibawa oleh siswa karena dalam diskusi nanti siswa membutuhkan spidol atau 
pensil warna untuk merancang peta pikirannya. Sementara, hanya beberapa siswa yang membawa spidol atau pensil warna. Jadi, guru mengatur sedemikian rupa agar semua kelompok memiliki spidol atau pensil warna. Kemudian membagikan Lembar Kerja Kelompok (LKK), menjelaskan petunjuk kerja, dan mempersilahkan siswa berdiskusi/bertanya jawab dengan teman kelompoknya seputar materi tentang "Perkembangan Teknologi Komunikasi" yang baru saja dijelaskan oleh guru.

Pada tahap mengamati dan membimbing siswa dalam merancang peta pikiran, kegiatan yang dilakukan dalam tahap ini adalah guru membimbing setiap kelompok dalam merancang peta pikiran sesuai petunjuk kerja pada LKK yang telah dibagikan. Pada tahap ini, guru mempersilahkan kepada siswa langsung bertanya ketika mendapat kesulitan dalam merancang peta pikiran tentang "Perkembangan Teknologi Komunikasi". Sementara kegiatan yang dilakukan siswa merancang peta pikiran sesuai kreativitasnya masing-masing.

Pada tahap mengamati dan membimbing siswa saat presentase, kegiatan yang dilakukan pada tahap ini adalah guru mengacak kelompok siswa untuk melakukan presentase di depan guru dan dan teman-teman lainnya. Siswa secara bergantian menyampaikan atau mempresentasekan hasil kerja kelompok mereka diselingi dengan pemberian penguatan oleh guru untuk percaya diri membacakan hasil kerja kelompok di depan guru dan teman-teman lainnya agar siswa terbiasa berbicara di depan umum.

Pada tahap menyimpulkan pembelajaran, guru mengarahkan siswa untuk merumuskan kesimpulan berdasarkan pelajaran. Guru membimbing siswa untuk menyampaikan apa yang telah siswa ketahui tentang materi pelajaran yang telah dipelajari mengenai "Perkembangan Teknologi Komunikasi". Siswa secara bergantian mengeluarkan pendapat mereka berdasarkan apa yang telah siswa ketahui.

Pelaksanaan pertemuan dua, antara lain sebagai berikut :

Pada tahap kegiatan inti pembelajaran, guru memulai pembelajaran dengan melaksanakan langkah-langkah model pembelajaran Mind Mapping yaitu:

Pada tahap menyampaikan tujuan pembelajaran, kegiatan yang dilakukan guru adalah menuliskan dan menyampaikan serta menjelaskan tujuan pembelajaran, kemudian siswa dipersilahkan menuliskan tujuan pembelajaran tersebut. Pada tahap ini guru juga menjelaskan kepada siswa manfaat mempelajari tentang "Perkembangan Teknologi Transportasi”. Pada tahap ini, guru juga menyampaikan kompetensi yang akan dilakukan oleh siswa nantinya.

Pada tahap menyajikan materi pelajaran, kegiatan yang dilakukan pada pembelajaran ini yaitu, guru menjelaskan pengertian teknologi dan "Perkembangan Teknologi Transportasi" dengan memanfaatkan media yang telah disediakan. Sementara siswa menyimak penjelasan materi pelajaran tersebut diselingi juga dengan tanya jawab antara guru dan siswa sebagi bentuk respon siswa terhadap penyampaian materi pelajaran tersebut.

Pada tahap membagi siswa kedalam bentuk kelompok, Guru megelola kelas dalam bentuk kelompok kecil dimana pada saat itu siswa dibagi menjadi 13 kelompok yang masing-masing kelompok beranggotakan 2 orang siswa setiap kelompoknya. Guru membagi kelompok sesuai kelengkapan alat yang telah dibawa oleh siswa karena dalam diskusi nanti siswa membutuhkan spidol atau pensil warna untuk merancang peta pikirannya. Sementara, hanya beberapa siswa yang membawa spidol atau pensil warna. Jadi, guru mengatur sedemikian rupa agar semua kelompok memiliki spidol atau pensil warna. Kemudian membagikan Lembar Kerja Kelompok (LKK), menjelaskan petunjuk kerja, 
dan mempersilahkan siswa berdiskusi/bertanya jawab dengan teman kelompoknya seputar materi tentang "Perkembangan Teknologi Transportasi" yang baru saja dijelaskan oleh guru.

Pada tahap mengamati dan membimbing siswa dalam merancang peta pikiran, kegiatan yang dilakukan dalam tahap ini adalah guru membimbing setiap kelompok dalam merancang peta pikiran sesuai petunjuk kerja pada LKK yang telah dibagikan. Pada tahap ini, guru mempersilahkan kepada siswa langsung bertanya ketika mendapat kesulitan dalam merancang peta pikiran tentang "Perkembangan Teknologi Transportasi". Sementara kegiatan yang dilakukan siswa merancang peta pikiran sesuai kreativitas mereka masing-masing.

Pada tahap mengamati dan membimbing siswa saat presentase, kegiatan yang dilakukan pada tahap ini adalah guru mengacak kelompok siswa untuk melakukan presentase di depan guru dan dan teman-teman lainnya. Siswa secara bergantian menyampaikan atau mempresentasekan hasil kerja kelompok mereka diselingi dengan pemberian penguatan oleh guru untuk percaya diri membacakan hasil kerja kelompok di depan guru dan teman-teman lainnya agar siswa terbiasa berbicara di depan umum.

Pada tahap menyimpulkan pembelajaran, guru mengarahkan siswa untuk merumuskan kesimpulan berdasarkan pelajaran. Guru membimbing siswa untuk menyampaikan apa yang telah siswa ketahui tentang materi pelajaran yang telah dipelajari mengenai "Perkembangan Teknologi Transportasi". Siswa secara bergantian mengeluarkan pendapat mereka berdasarkan apa yang telah siswa ketahui.

Pada akhir pembelajaran, guru memberikan tes evaluasi akhir siklus yang bertujuan untuk mengecek apakah siswa sudah benar-banar memahami materi pembelajaran dan mengukur pencapaian keberhasilan belajar pada siklus II. Guru membagikan lembar tes kepada seluruh siswa berupa tes tertulis sebanyak 10 nomor dalam bentuk multiple choice (pilihan ganda) dan mempersilahkan kepada siswa untuk mengerjakan tes secara individu dan siswa tidak diperkenankan bekerjasama atau mencari jawaban di buku. Selanjutnya guru memberikan pesan moral untuk mensyukuri adanya perkembangan teknologi dan memanfaatkan teknologi sebaik-baiknya dan tidak menyalahgunakan perkembangan teknologi, dan tepat pada pukul 09.15 WITA guru mengakhiri pembelajaran dengan salam dan pembelajaran selesai.

Hasil evaluasi akhir siklus II menunjukkan siswa berada telah mencapai keberhasilan belajar sebagaimana yang telah ditargetkan yaitu minimal $76 \%$ siswa mencapai nilai $K K M \geq 70$. Pencapaian hasil belajar pada siklus II yaitu $88 \%$ siswa telah memperoleh nilai berdasarkan $\mathrm{KKM} \geq 70$ sebagaimana lengkap terlampir pada lampiran 24 halaman 125. Sehingga dapat disimpulkan pada siklus II telah mencapai keberhasilan belajar dan penelitian dihentikan pada siklus II.

3. Observasi

Temuan hasil observasi terhadap guru berdasarkan dari seluruh rangkaian kegiatan pembelajaran yang dilakukan pada siklus II tentang aktivitas guru, yaitu :

a) Pada tahap menyampaikan tujuan pembelajaran, 3 dari 3 deskriptor terlaksana dengan baik (B) pada pertemuan pertama dan kedua.

b) Pada tahap menyajikan materi pelajaran, pertemuan pertama 2 dari 3 deskriptor terlaksana yaitu menjelaskan materi sesuai indikator pembelajaran dan menjelaskan secara singkat dan sistematis. Namun, masih terdapat bahasa yang sulit dipahami oleh siswa sehingga pada tahap ini masih berada pada kategori cukup (C). Kemudian meningkat pada pertemuan kedua dimana 3 
dari 3 deskriptor telah terlaksana sehingga berkategori baik (B).

c) Pada tahap membagi siswa menjadi 13 kelompok yang beranggotakan 2 siswa perkelompok, 3 dari 3 deskriptor terlaksana pada pertemuan pertama dan kedua sehingga berada pada kategori baik (B).

d) Pada tahap mengamati dan membimbing siswa saat merancang peta pikiran, 3 dari 3 deskriptor terlaksana pada pertemuan pertama dan kedua sehingga berada pada kategori baik (B).

e) Pada tahap mengamati dan membimbing siswa saat mempresentasekan, 3 dari 3 deskriptor terlaksana pada pertemuan pertama dan kedua sehingga berada pada kategori baik (B).

f) Pada tahap menyimpulkan, pertemuan pertama dan kedua 2 dari 3 deskriptor terlaksana yaitu mengarahkan siswa merumuskan dan membacakan kesimpulan namun, tidak menuliskan. Sehingga tahap ini berkategori cukup (C).

Hasil observasi terhadap aktivitas guru pada Siklus II kemampuan guru dalam mengajarkan materi "Perkembangan Teknologi Komunikasi" dan "Perkembangan Teknologi Transportasi" dengan menggunakan model pembelajaran Mind Mapping termasuk dalam kategori baik. Pada pertemuan pertama siklus II mencapai presentase $88,88 \%$ dan pertemuan kedua $94,44 \%$ atau berada pada kategori baik (B).

Adapun aktivitas siswa dalam proses pembelajaran, tidak ada yang berada pada kategori kurang $(\mathrm{K})$ secara keseluruhan hanya berada pada kategori baik (B) dan sebagian pada kategori (C). Secara jelas dapat diuraikan sebagai berikut:

a) Pada tahap menyimak ulasan tujuan pembelajaran, pertemuan pertama 10 kelompok berada pada kategori baik (B), dan 3 kelompok berada pada kategori cukup (C). Kemudian meningkat pada pertemuan kedua dimana 11 kelompok berada pada kategori baik (B) dan tersisa 2 kelompok berada pada kategori cukup (C).

b) Pada tahap menyimak ulasan materi pelajaran, pertemuan pertama 6 kelompok berada pada kategori baik (B), selebihnya 7 kelompok berada pada kategori cukup (C). Kemudian meningkat pada pertemuan kedua dimana 10 kelompok berada kategori baik (B), selebihnya 3 kelompok berada pada kategori cukup (C).

c) Pada tahap berdisusi dengan teman kelompok, pertemuan pertama 8 kelompok berada pada kategori baik (B), selebihnya 5 kelompok berada pada kategori cukup (C). Kemudian meningkat pada pertemuan kedua dimana 9 kelompok berda pada kategori baik (B), dan tersisa 4 kelompok berada pada kategori cukup (C).

d) Pada tahap merancang peta pikiran, pertemuan pertama 8 kelompok berada pada kategori baik (B), 5 kelompok berada pada kategori cukup (C). Kemudian meningkat pada pertemuan kedua dimana 9 kelompok berada pada kategori baik (B), dan tersisa 4 kelompok berada pada kategori cukup (C).

e) Pada tahap mempresentasekan, pertemuan pertama 5 kelompok berada pada kategori baik (B), dan 8 kelompok berada pada kategori cukup (C). Kemudian meningkat pada pertemuan kedua dimana 7 kelompok berada pada kategori baik (B), dan tersisa 6 kelompok berada pada kategori cukup (C).

f) Pada tahap menyimpulkan, pertemuan pertama 5 kelompok berada pada kategori baik (B), dan 8 kelompok berada pada kategori cukup (C). Kemudian meningkat pada pertemuan kedua dimana 7 kelompok berada pada kategori baik (B), selebihnya 6 kelompok berada pada kategori cukup (C).

Berdasarkan observasi tersebut presentase keseluruhan aktivitas siswa pada proses pembelajaran pada pertemuan pertama yaitu $82,47 \%$ meningkat pada pertemuan 
kedua dengan presentase $88,45 \%$ atau berada pada kategori baik (B).

4. Refleksi

Berdasarkan hasil observasi dan evaluasi yang telah dilakukan oleh peneliti dan observer pada pelaksanaan siklus II ternyata mengalami peningkatan yang sangat signifikan dibanding dengan siklus sebelumnya. Hal ini terlihat pada hasil observasi guru (peneliti) dan siswa serta perolehan nilai dari siswa secara kelompok maupun individual. Hasil analisis dan refleksi dari kegiatan yang terjadi pada tindakan siklus II ini adalah sebagai berikut:

a) Peneliti telah menyajikan atau menjelaskan materi pelajaran secara sistematis dan dengan bahasa yang mudah dipahami oleh siswa.

b) Peneliti telah membagi kelompok secara teliti.

c) Pengaturan waktu yang dilakukan oleh guru untuk setiap langkah-langkah pembelajaran sudah baik dan efisien. Sedangkan hasil observasi terhadap aktivitas siswa menunjukan hal-hal sebagai berikut:

a) Siswa telah memahami cara membuat catatan kecil/merancang peta pikiran.

b) Siswa sudah berani mengeluarkan pendapatnya.

Sehingga dapat disimpulkan pada siklus II bahwa:

a) Guru mampu melaksanakan pembelajaran dengan baik sesuai dengan langkah-langkah yang terdapat dalam menerapakan model pembelajaran Mind Mapping mulai dari tahap menyampaikan tujuan pembelajaran, menjelaskan materi pelajaran, membagi siswa kedalam bentuk kelompok, mengamati dan membimbing siswa saat membuat merancang peta pikiran, membimbing dan mengamati siswa saat presentase, meskipun pada tahap menyimpulkan masih pada kategori cukup.

b) Guru mampu mengelolah kelas dengan baik sehingga seluruh siswa antusias dalam memperhatikan penjelasan guru. c) Siswa termotivasi untuk membuat catatan kecil/merancang peta pikiran yang lebih kreatif dari yang sebelumnya.

d) Waktu pembelajaran berlangsung sesuai dengan yang direncanakan.

Penelitian tidak dilanjutkan lagi pada siklus berikutnya karena pencapaian ketuntasan hasil belajar siswa telah memenuhi kriteria atau indikator pencapaian telah berhasil.

\section{KESIMPULAN}

Berdasarkan data dan pengamatan dari siklus ke siklus dalam penelitian ini dapat disimpulkan :

1. Penerapkan model pembelajaran Mind Mapping menunjukkan hasil yang positif, karena dalam mind mapping siswa selama pembelajaran diberikan kesempatan berkomunikasi dengan teman lainnya dalam memecahkan masalah yang diberikan, siswa juga dapat mengembangkan kreativitas melalui kerjasama merancang peta pikiran dari materi pelajaran yang telah dibahas. Siswa tidak lagi disulitkan dengan mencatat keseluruhan pembahasan pembelajaran, siswa hanya mencatat kata kunci kemudian merancang peta pikirannya dengan begitu siswa lebih mudah mengingat dan memahami pembelajaran.

2. Pembelajaran yang menerapkan model pembelajaran Mind Mapping dengan baik dan benar dapat meningkatkan hasil belajar IPS siswa.

\section{DAFTAR PUSTAKA}

Buzan, Tony. 2008. Buku Pintar Mind Map. Jakarta: PT. Gramedia Pusaka Utama.

BSNP. 2006. Pedoman Penyususnan Kurikulum Tingkat Satuan Penddidikan Sekolah Dasar. Jakarta: BSNP.

Djamarah, dkk. 2006. Strategi Belajar Mengajar. Jakarta : PT. Rineka Cipta. 
Shoimin, Aris. 2014. Model Pembelajaran Inovatif dalam Kurikulum 2013. Jakarta: Ar-Ruzz Media.

Swadarma, Doni. 2013. Penerapan Mind Mapping dalam Kurikulum Pembelajaran. Jakarta: PT. Elex Media Kompetindo. 